\title{
PENGARUH TERAPI BERMAIN MEWARNAI GAMBAR TERHADAP TINGKAT KECEMASAN ANAK USIA PRASEKOLAH AKIBAT HOSPITALISASI DI RUANGAN ANAK DI RUMAH SAKIT ADVENT BANDAR LAMPUNG
}

\author{
THE INFLUENCE OF PLAY THERAPY BY COLORING ON THE LEVEL OF \\ ANXIETY IN PRASECHOOL AGED CHILDREN HOSPITALISED IN THE \\ PEDIATRIC WARD OF BANDAR LAMPUNG ADVENTIST HOSPITAL
}

Debilly Boyoh ${ }^{1}$, Elisa Magdalena ${ }^{2}$

Fakultas IImu Keperawatan, Universitas Advent Indonesia

Email: debily.boyoh@unai.edu

\begin{abstract}
ABSTRAK
Pendahuluan: Latar belakang penelitian ini adalah anak yang mengalami kecemasan akibat hospitalisasi. Akibat hospitalisasi dapat mengakibatkan kecemasan pada anak usia prasekolah dan dampak kecemasan tersebut dapat menghambat perkembangan Tumbuh kembang anak tersebut. Pengalaman penulis saat berperaktek di rumah sakit sering mendapatkan anak yang mengalami kecemasan akibat hospitalisasi. Tujuan: Untuk mengurangi tingkat kecemasan tersebut anak dapat diberikan terapi bermain mewarnai gambar. Metode: Penelitian ini menggunakan desain penelitian Quasi eksperimen dengan teknik pengambilan sampel yang menggunakan metode total sampling dan kuota waktu. Kemudian data analisis dengan menggunkan uji Mann Whitney. Hasil: Dari total keseluruhan jumlah responden 15 anak usia prasekolah yang dirawat di Rumah Sakit Advent Bandar Lampung menunjukkan bahwa nilai $p$ value $=0,000(<0,05)$ sehingga ada pengaruh terapi bermain pada anak usia prasekolah akibat hospitalisasi di ruangan anak Rumah Sakit Advent Bandar Lmapung. Diskusi: Keperawatan anak dapat menyediakan ruangan untuk bermain dan menfasilitaskan alat bermain sehingga anak dapat merasakan relaksasi pada saat menjalani proses perawatan di hospitalisasi.
\end{abstract}

Kata Kunci: Hospitalisasi, Kecemasan, terapi Bermain

\begin{abstract}
Introduction: The background of this study is children who experience anxiety due to hospitalization. As a result of hospitalization can lead to anxiety in preschoolers and the effects of anxiety can inhibit the development of the child's growth. The author's experience when practicing in the hospital often get children who experience anxiety due to hospitalization. Purpose: To reduce the level of anxiety, the child can be given coloring therapy to play the picture. Method: This research used a Quasi experimental research design with research sampling technique using total sampling method and time quota. Then data analysis by using Mann Whitney test. Results: From the total number of respondents 15 preschool age children who were treated at Advent Bandar Lampung Hospital, showed that $p$ value $=0.000(<0,05)$ so that there is influence of play therapy on preschool age children due to hospitalization in child's room Advent Hospital Bandar Lampung. Discussion: Nursing a child can provide a room to play and facilitate the playground so that the child can feel relaxation while undergoing the process of hospitalization.
\end{abstract}

Keywords: Hospitalization, Anxiety, Play Therapy
JURNAL

SKOLASTIK

\section{KEPERAWATAN}

Vol, 4 , No. 2

Juli - Desember 2018

ISSN: $2443-0935$

E-ISSN 2443 - 16990 


\section{PENDAHULUAN}

Anak adalah individu yang bergantung pada orang dewasa dan lingkunganya, dimana anak membutuhkan lingkungan yang dapat menfasilitasi dalam memenuhi kebutuhan dasarnya memerlukan perawatan dirumah sakit atau dikenal dengan nama hospitalisasi.

Hospitalisasi pada anak merupakan proses yang dikarenakan suatu alasan yang berencana atau darurat sehingga mengharuskan anak untuk tinggal di rumah sakit, menjalani terapi dan perawatan sampai pemulangannya kembali ke rumah (Rusmariana, Faridah \& Aryani, 2013).

Pada umumnya anak-anak yang mengalami hospitalisasi sering kali mengalami perpisahan dengan orang tuanya anak yang mengalami hospitalisasi harus dapat beradaptasi dengan lingkungan baru dan orangorang disekelilingnya, dampak dari ini anak dirawat atau hospitalisasi adalah ketakutan disekitarnya, kegelisahan, trauma dan cemas (Kartinawati,

Haryani \& Arif, 2013).

Anak sakit yang dengan hospitalisasi sering mengartikan sebagai hukuman, kemudian muncul rasa malu, takut, hal ini menjadikan anak bersikap agresif, marah, berontak, sering bertanya, tidak mau makan, tidak kooperatif hingga kehilangan controld dan terbatasnya aktifitas yang membuat perawatan dirumah sakit bisa terhambat (Aizah \& Ernawati 2014)

Ambarwati (2012) mengatakan bahwa dampak dari hospitalisasi anak dapat menimbulkan kecemasan dan stress pada semua tingkatan usia. Kecemasan dan stress yang dialami anak saat Hospitalisasi dipengaruhi oleh beberapa faktor antara lain faktor dari petugas kesehatan, perawat, dokter, dan tenaga kesehatan lainnya. Anakanak yang datang ke rumah sakit dengan hospitalisasi dapat mengcemaskan dan mengalami yang lebih serius dan komplek sehingga dapat menimbulkan stress (Hockenberry \& Wilson, 2009).

Menurut Sumayoko (2008) dalam survey ekonomi Nasional (SUSENAS) tahun 2010 jumlah anak usia prasekolah (3-6 tahun) adalah 72\% dari jumlah total penduduk Indonesia. 35 per 100 anak menjalankan Hospitalisasi dan $45 \%$ menjalani kecemasan Penelitian yang dilakukan Kholisatum (2013) di ruang RS BAPTIS KEDIRI jumlah pasien anak usia 3-6 tahun didapatkan anak $10(6 \%)$ menunjukan respon terhadap hospitalisasi adalah dengan menangis, takut, tidak kooperatif terhadap petugas kesehatan, tidak mau makan dan selalu bertanya kepada ibunya kapan bisa pulang sedangkan $5 \quad(3 \%)$ menunjukkan respon adaptif terhadap Hospitalisasi, yaitu dengan menunjukkan respon kooperatif dengan petugas kesehatan dan mau minum obat (Desita, \& Febriana, 2011).

Dampak hospitalisasi pada anak dapat di kurangi dengan terapi bermain dengan mewarnai. Hasil penelitian Katinawati, Haryani, dan Arif (2013) menjelaskan bahwa sebelum diberikan terapi bermain mewarnai sebagian besar anak mengalami kecemasan 
sedang $11(73,33 \%)$ dan anak dengan cemas sedang berat $4(26,66 \%)$ anak yang telah diberikan tehnik mewarnai menunjukkan hasil cemas ringan 13 $(86,6 \%)$ anak dan cemas sedang 2 $(13,3 \%)$.

Terapi bermain mewarnai sangat membantu anak mengatasi tingkat kecemasan yang sangat berlebihan dan sangat baik untuk beradaptasi dengan lingkungan sekitarnya dan suasana teman baru bahkan dengan team medis dalam pemberian obat. Terapi bermain mewarnai sangat mudah untuk dilakukan dan tidak terlalu banyak memerlukan biaya. Dalam penelitian Wowiling, Ismanto, dan Babakal (2013) menjelaskan bahwa terjadi penurunan tingkat kecemasan anak usia prasekolah yang mengalami hospitalisasi yang berarti pengaruh terapi bermain mewarnai gambar terhadap tingkat kecemasan pada anak usia prasekolah akibat hospitalisasi.

Pengamatan penulis anak - anak yang mengalami kecemasan dalam proses hospitalisasi dan berdasarkan pengalaman selama praktek dirumah sakit advent bandung dan dirumah sakit advent bandar lampung didapati banyak anak usia prasekolah yang mengalami kecemasan, bedasarkan masalah diatas maka penulis tertarik melakukan penelitian dengan judul:

\begin{tabular}{|c|c|c|}
\hline \multirow{2}{*}{\multicolumn{3}{|c|}{$\begin{array}{lll}\text { "PENGARUH TERAPI } & \text { BERMAIN } \\
\text { MEWARNAI } & \text { GAMBAR }\end{array}$}} \\
\hline & & \\
\hline \multicolumn{3}{|c|}{$\begin{array}{ll}\text { MEWARNAI } & \text { GAMBAR } \\
\text { TERHADAP } & \text { TINGKAT }\end{array}$} \\
\hline \\
\hline \multirow{2}{*}{\multicolumn{3}{|c|}{$\begin{array}{l}\text { PRASEKOLAH } \\
\text { HOSPITALISASI }\end{array}$}} \\
\hline & & KUAINGAIN \\
\hline \multicolumn{3}{|c|}{ ANAK DI RUMAH SAKIT ADVENT } \\
\hline & & \\
\hline
\end{tabular}

\section{BAHAN DAN METODE}

Desain penelitian yang digunakan dalam penelitian ini adalah eksperimen semu, eksperimen semu adalah desain eksperimen yang tidak mengambil subjek secara acak dari populasi tetapi menggunakan seluruh subjek dalam kelompok yang utuh (Sugiono, 2007). penelitian ini adalah pengaruh terapi bermain terhadap tingkat kecemasan anak usia prasekolah akibat hospitalisasi

Sampel dalam penelitian ini dipilih dengan menggunakan total sampling dengan quota waktu. total sampling adalah sampel jenuh dengan cara tehnik penentuan sampel dengan cara mengambil seluruh anggota populasi sebagai responden atau sampel. Sampel penelitian ini adalah 15 anak usia pra sekolah yang di hospitalisasi, berdasarkan kuotawaktu. Sampling sebanyak 15 responden yang memenuhi kriteria sampling yaitu:

1. Subjek yang di teliti merupakan anak usia prasekolah (3-6 Tahun), yang sedang mengalami kecemasan di hospitalisasi, atas seijin orang tua bersedia untuk menerima terapi bermain mewarnai gambar, atas seijin orang tua yang mau menandatangani infromed concent dan tidak memakai subjek yang sedang mengalami buta warna, total care selama perawatan di rumah sakit dan orang tua yang tidak mau mendatangani infromed concent.

2. Objek yang diteliti adalah anak usia prasekolah (3-6 tahun) yang sedang mengalami kecemasan akibat hospitalisasi dengan memberikan terapi bermain mewarnai gambar. 
3. Perolehan data hanya berdasarkan hasil pengumpulan data dari eksperimen yang dilakukan responden

4. Responden yang diambil sudah dirawat inap selama 2 hari tidak mengalami demam, sesak, dan keadaannya yang stabil

\section{HASIL PENELITIAN}

Hasil penelitian ini diperoleh hasil dari 15 responden penelitian di Rumah Sakit Advent Bandar Lampung dianalisis berdasarkan ketiga indentifikasi masalah data yang dikumpulkan kemudian di interprestasikan

1. Berapakah tingkat kecemasan anak usia prasekolah sebelum diberikan terapi bermain? Maka tingkat kecemasan dari 15 responden sebelum diberikan intervensi selama 15 menit dihitung berdasarkan rumus (mean) menggunakan SPSS, maka hasil yang didapatkan adalah sebagia berikut.

Tabel 1. Tingkat Kecemasan Sebelum diberikan Terapi Bermain

\begin{tabular}{lllll}
\hline $\begin{array}{l}\text { Tingkat } \\
\text { kecemasan }\end{array}$ & $\mathbf{N}$ & Mean & SD & Interpretasi \\
\hline Sebelum & 15 & 3,20 &, 775 & $\begin{array}{l}\text { Kecemasan } \\
\text { berat }\end{array}$ \\
\hline
\end{tabular}

Tabel 1. menunjukkan bahwa tingkat kecemasan sebelum diberikan terapi bermain adalah 3,20. Menurut kategori face smile scale pada table 2.1 nilai tersebut msuk kedalam katagori kecemasan sedang $(\mathrm{SD}=0,775)$.
2. Bagaimana tingkat kecemasan anak usia prasekolah sesudah melakukan terapi bermain mewarnai?". Setelah mengetahui bahwa data tidak terdistribusi normal, maka dilakukan uji hipotesa dengan uji Mann Whitney Pengujian ini dilakukan untuk melihat terhadap Tingkat kecemasan anak usia prasekolah akibat hospitalisasi dirumah sakit advent bandar lampung.

Tabel 2. Tingkat Kecemasan sesudah diberikan terapi bermain.

\begin{tabular}{|l|l|l|l|l|}
\hline $\begin{array}{l}\text { Tingkat } \\
\text { Kecema } \\
\text { san }\end{array}$ & N & $\begin{array}{l}\text { Mea } \\
\mathrm{n}\end{array}$ & SD & $\begin{array}{l}\text { Interpret } \\
\text { asi }\end{array}$ \\
\hline Sesudah & 1 &, 73 & $\begin{array}{l}, 79 \\
9\end{array}$ & $\begin{array}{l}\text { Kecema } \\
\text { san } \\
\text { Ringan }\end{array}$ \\
\hline
\end{tabular}

Tabel 2. dapat diketahui bahwa tingkat kecemasan sesudah mewarnai adalah ,73. Menurut kategori tingkat kecemasan pada tabel 3.1, tingkat kecemasan tersebut masuk kedalam kategori kecemasan Ringan $(\mathrm{SD}=0,799$

3. Adakah perbedaan efektivitas yang signifikan antara tingkat kecemasan anak usia prasekolah sebelum dan sesudah melakukan mewarnai?", maka dilakukan uji hipotesa dengan uji $t$ berpasagan $(t$ paired t-test) menggunakan SPSS maka hasil yang didapatkan adalah sebagai berikut: 
Tabel 3. Rata - rata kecemasan sesudah dan sebelum

\begin{tabular}{|l|l|l|l|l|l|}
\hline $\begin{array}{l}\text { Tingkat } \\
\text { kecemasan }\end{array}$ & Mean & SD & T & Df & $\begin{array}{l}\text { P } \\
\text { value }\end{array}$ \\
\hline $\begin{array}{l}\text { Kecemasan } \\
\text { Pre }\end{array}$ & 2,4 & 8 & 11,4 & 1 & 0,0 \\
\hline $\begin{array}{l}\text { Kecemasan } \\
\text { Post }\end{array}$ & 67 & 34 & 57 & 4 & 00 \\
\hline
\end{tabular}

Bedasarkan hasil olah data menggunakan uji $\mathrm{t}$ berpasangan $(\mathrm{t}$ paired t-test) didapatkan bahwa nilai mean antara sebelum dan sesudah adalah 2,476 dengan standar deviasi ,834 dengan nilai thitung 11,457 dan df 14 maka nilai sig (2-tailed) adalah 0.000 .

Sunyoto (2012) mengatakan pada kriteria pengujian dua pihak bila thitung $>$ tabel maka Ha diterima dimana terdapat perbedaan yang signifikan anatara 2 variabel. Dengan demikian, maka thitung>ttabel. Berarti nilai Ho ditolak dan Ha diterima dengan signifikan pada taraf kepercayaan $95 \%$. Nilai $\alpha=0.05$ dan $\mathrm{dk}=15-1=14$. Hasil dalam pengelolahan data terdapat perbedaan signifikan terhadap nilai tingakt kecemasan pada anak usia prsekolah di Rumah Sakit Advent Bandar Lampung.

\section{PEMBAHASAN}

\section{Berapakah tingkat kecemasan anak usia prasekolah sebelum diberikan terapi bermain}

Analisa data di atas menunjukan bahwa tingkat kecemasan sebelum melakukan terapi bermain mewarnai gambar adalah 3,20 dengan standar devisiasi ,775 dan masuk ke dalam katagori kecemasan berat. Berdasarkan hasil observasi dan analisis peneliti sebelum melakukan terapi bermain mewarnai gambar tingkat kecemasan anak usia prasekolah disebabkan oleh karena perpisahan dengan orangtua sehingga dapat memicu terjadinya kecemasan pada anak. Kecemasan dan stress pada anak yang dialami saat hospitalisasi dipengaruhi oleh beberapa faktor anatara lain dari petugas kesehatan, perawat, dokter, dan tenaga kesehatan lainnya. Kecemasan berat akibat hospitalisasi menimbulkan traumatis dan dapat merusak kepribadian individu dan dapat menghambat perkembangan Tumbuh kembang anak tersebut. Potter \& Perry (2015) menyatakan usia prasekolah merupakan masa kanakkanak awal yaitu pada usia 3-6 tahun. Pada usia ini, perkembangan motorik anak berjalan terus-menerus, reaksi kecemasan pada anak tersebut dapat ditunjukan dengan menolak makan, sering bertanya, menangis walaupun secara perlahan dan tidak dapat kooperatif terhadap petugas kesehatan dalam memberikan pelayanan. Maka dari itu peran orangtua sangat dibutuhkan dalam mendampingi anak selama proses perawatan di rumah sakit dan dapat membantu dalam memenuhi kebutuhan dasar anak selama proses perawatan (Wowilling, dkk 2014).

\section{Bagaimana tingkat kecemasan anak usia prasekolah sesudah melakukan terapi bermain mewarnai}

Analisa data diatas menunjukkan bahwa tingkat kecemasan sesudah melakukan mewarnai adalah ,73 dengan standard devisiasi ,799 dan 
masuk kedalam kategori tingkat kecemasan Ringan. Berdasarkan hasil observasi dan analisis peneliti sesudah melakukan terapi bermain mewarnai gambar tingkat kecemasana anak usia prasekolah terjadinya penurunan kecemasan dikarenakan dapat mengalihkan perhatian anak akan suatu objek yang mencemaskan, bermain dapat dilakukan terhadap anak yang sakit maupun anak yang sehat. Walaupun anak sedang mengalami sakit, tetapi kebutuhan akan bermain tetap ada (Suryanti, 2011). Bermain akan sangat disukai dikarenakan membuat anak senang pada saat permainan mewarnai gambar, bermain juga merupakan cerminan kemampuan fisik, intelektual, emosional dan sosial dan bermain merupakan media yang baik untuk belajar menyesuaikan diri terhadap lingkungan dan melakukan apa yang dapat dilakukan (Wong, 2009). Salah satu permainan yang cocok dilakukan untuk anak usia prsekolah yaitu mewarnai gambar, dimana anak menyukai dan mengenal warna serta mengenal bentuk-bentuk benda di sekelilingnya (Suryanti, 2011)

\section{Adakah perbedaan efektivitas yang signifikan antara tingkat kecemasan anak usia prasekolah sebelum dan sesudah melakukan mewarnai}

Analisa data menunjukkan bahwa terapi mewarnai memiliki nilai pvalue $<0.05$ yang menyatakan bahwa adanya perbedaan yang signifikan pada tingkat kecemasan anak usia prasekolah. Dengan Hipotesa (Ho) yang menyatakan tidak ada perbedaan yang signifikan pada terapi bermain mewarnai gambar, ditolak dan hasil dari Hipotesa (Ha) yang menyatakan bahwa ada perbedaan yang signifikan pada terapi bermain mewarnai pada anak usia prasekolah, diterima.

Penelitian ini sama dengan hasil penelitian (Wowiling, dkk 2014) adanya pengaruh terapi bermain terhadap tingkat kecemasan anak usia prasekolah yang mengalami tingkat kecemasan akibat hospitalisasi, dari hasil penelitian menunjukkan bahwa anak usia prasekolah mengalami penurunan tingkat kecemasan setelah dilakukan terapi mewarnai gambar, terapi mewarni gambar merupakan salah satu tehnik yang dapat mengalihkan perhatian anak usia prasekolah yang mengalami kecemasan akibat hospitalisasi.

Kecemasan yang terus-menurus yang dialami anak akan dapat menghambat perkembangan tumbuh kembang anak, anak sering menangis tidak mau berinteraksi dengan perawat maupun tenaga kesehatan lainnya anak tidak ingin dilakukan tindakan keperawatan seperti pemberian obat, pemasangan infus, pengambilan darah, maupun tindakan keperawatan lainnya. Anak sering kali mengartikan bahwa perawat dan tenaga medis lainnya hanyalah untuk menyakiti dirinya. Dengan memberikan terapi bermain dapat membuat anak menjadi relaksasi dan dapat mengekspresikan perasaannya, berinteraksi dengan suasana lingkungan baru dan orangorang disekelilingnya, sehingga anak tidak mempunyai rasa takut terhadap perawat dan tenaga kesehatan lainnya anak dapat berkooperatif selama tindakan keperawatan yang dilakukan 
pada saat proses perawatan dirumah sakit, bermain sangat digemari setiap anak yang sedang sakit maupun anak yang sehat dikarenakan dapat membuat perasaannya senang dan dapat meningkatkan system motoriknya menurut (Wong, 2009), bermain merupakan kegiatan anak-anak, yang dilakukan berdasarkan keinginannya sendiri untuk mengatasi kesulitan, stress dan tantangan yang ditemui serta berkomunikasi untuk mencapai kepuasan dalam berhubungan dengan orang lain

\section{KESIMPULAN}

1. Tingkat kecemasan sebelum dilakukan terapi bermain adalah 3,20 Dan masuk kedalam kategori tingkat kecemasan Berat

2. Berdasarkan hasil penelitian yang dilakukan maka tingkat kecemasan sesudah melakukan terapi bermain mewarnai gambar adalah 0.73 Dan masuk kedalam kategori tingkat kecemasan Ringan

3. Ada perbedaan yang signifikan terhadap tingkat kecemasan anak usia prasekolah sebelum dan sesudah melakukan terapi bermain mewarnai gambar pada pasien di Rumah Sakit Advent Bandar Lampung

\section{SARAN}

1. Agar dapat melakukan terapi non farmakologi gambar untuk menurunkan tingkat kecemasan dengan cara mewarnai gambar.

2. Perawat dan tenaga kesehatan dapat menggunakan terapi bermain mewarnai gambar untuk mengatasi kecemasan pada saat dilakukan tindakan keperawatan dengan berdasarkan evidence base practice. Keperawatan anak dapat menyediakan alat bermain dan ruangan bermain anak untuk mengurangi dampak hospitalisasi selama proses perawatan, permainan yang diberikan kepada anak yang dirawat berupa gambar buah-buahan dan sayur-sayuran sederhana agar diwarnai sehingga kecemasan anak dapat berkurang.

3. Rumah sakit dapat memberikan fasilitas bermain di ruangan anak sehingga anak dapat relaksasi selama proses perawatan berlangsung.

4. Sebagai motivasi bagi diri sendiri untuk mengurangi kecemasan dalam mengerjakan skripsi.

5. Hasil penelitian ini diharapkan dapat digunakan sebagai data dasar untuk mengembangkan penelitian mengenai tingkat kecemasan pada anak usia prasekolah yang sedang mengalami hospitalisasi dan cara mengatasinya.

\section{DAFTAR PUSTAKA}

Arikunto, S. (2006). Prosedur Penelitian Suatu Pendeketan Praktik (6 thn ed.) Jakarta: PT Rineka Cipta

A. Aziz Alimul Hidayat. 2008. Pengantar Ilmu Keperawatan Anak I. Jakarta = Salemba Medika.

Azizah \& Ernawati (2014) pengaruh terapi bermain Walkie terhadap kecemasan akibat Hosipitalisasi di Rsud Dr. Moewardi 
Dahlan, M.S. (2008) Statistik untuk kedokteran dan kesehatan. Jakarta: Salemba Medika

Damayanti, M, \& Iskandae. (2012). Asuhan Keperawatan Jiwa.Bandung: PT Refika Aditama

Dewi, Kyrasein, Nyi. (2009). Factorfaktor yang mempengaruhi Tingkat Kecemasan Pasien yang akan Menghadapi Operasi di RSUD Fatmawati Tahun. 2009, Skripsi. Jakarta: UIN Syarf Hidayatullah.

Hockenberry, M.J \& Wilson, D. (2009). Essential of Pediatric Nursing. St Louis Missoury: Mosby

Karen Lee Fontaine. 2009.Mental Health Nursing America $=$ Julce Levin Alexander

Katinawati, Haryani \& Arif, (2013) Pengaruh terapi bermain dalam menurunkan kecemasan pada anak usia prasekolah (3-5 tahun) yang mengalami hospitalisasi di rumah sakit tugurejo semarang

Kapti, Ahsan \& Istiqomah (2013) Pengaruh terapi bermain terhadap penurunan skor prilaku maladaptive anak usia prasekolah (3-5 tahun) mengalami Hospitalisasi di rumah sakit kabupaten kediri

Donna L. Wong(et.al). (2008). Buku Ajar Keperawatan Pediatrik Wong. Alih Bahasa: Agus
Sutarna, Neti. Juniarti, H.Y. Kuncoro. Editor edisi bahasaa Indonesia: Egi Komara Yudha...(et al.). edisi 6. Jakarta: EGC

Fauziah, Fitri dan Julianti widuri, 200, psikologi Abnormal Klinis Dewasa Jakarta: UI Press

Fradianto, (2014) pengaruh terapi bermain lilin terhadap penurunan tingkat kecemasan pada anak usia prasekolah yang mengalami hospitalisasi di rsud dr. soedarso pontianak

Gunarsa, S.D., \& Gunarsa, Y.S.D (2006). Psikologi Perkembangan Anak dan Remaja, Jakarta: Pt BPK Gunung Mulia

Hewari, D. (2009). Psikometri Alat Ukur (Skala) Kesehatan Jiwa. Jakarta: FKUL.

Hidayat, A.A. (2008). Pengantar Ilmu Keperawatan dan Teknik Analisis Data. (2007). Metode Penelitian Keperawatan dan Teknik Analisis Data Jakarta: Salemba Medika 